\title{
A Study of Academic Stress and Adjustment among Gujarati and English Medium School Students
}

\section{ABSTRACT:}

\author{
Dr. K. B. Chothani*
}

The basic aim of present investigation is that to study the influence of role of medium in the development of child's personality by academic stress and adjustment scales. Present study was undertaken to examine the level of academic stress and adjustment among Gujarati medium and English Medium School Students. For that purpose 120 students of class IX and $\mathrm{X}$ were selected randomly from different schools out of which 60 were taken from Gujarati medium school and the remaining 60 were taken from English Medium School. Abha Rani Bisht (BBS) scale for measuring academic stress was used to see the level of stress and Sinha and Singh Adjustment Inventory for school students was used to examine level of adjustment among the students. The data were analyzed by ' $\mathrm{t}$ ' test and ANOVA were applied to check the difference in significance between the entire two mediums of instruction. The main and internal effect has been discussed. Results indicated that level of academic stress was significantly higher among the English Medium school students where as Gujarati medium school students were significantly better in terms of their level of adjustment. The Medium of Mother tongue per both boys and girls adjustment level are high and academic stress level low than other medium of instruction at school level.

Keywords: Academic Stress, Adjustment, Gujarati and English Medium School Students

\section{INTRODUCTION}

Language is an important factor in an interpersonal relationship. (Ganguly 1996) Language is viewed to be an instrument for social interaction it engaged people in the net work of an activity which yields data for social scientists to study the contours of social conduct of the individual to speak it. Knowingly or unknowingly we all are having a grip of western culture. The western culture can also be seen in our education system. Most of the school students are having their education in that language on which they have a very loose grip. As a result students are mugging the concepts of his subject in place of understanding the same. On the other side student who is having education in his mother tongue or local language will understand the concept in a better way.

\footnotetext{
*Associate Professor, Dept. of Psychology, C. U. Shah Arts College, Ahmedabad.
} 
Stress and anxiety in children and teenagers are just as prevalent as in adults. Negligence of parents, high expectations in academic or other performances, abused childhood, growing up tensions and demand for familial responsibility etc. the main causes of childhood and teen stress. Parents, who are not emotionally available for their children or lack positive coping mechanisms themselves, often spur stress in their offspring.

Stressed children show signs of emotional disabilities, aggressive behavior, shyness, social phobia and often lack interest in otherwise enjoyable activities. In a study Dawood (1995) found that students stress affects their academic performance. He further showed that the most frequently mentioned stressor by students was school and fear related stressors. Many teenagers tend to become non conformist and fall prey to teenage depression in response to a variety of growing up anxieties. However, stress induced fears and anxiety in children adversely affects children's performances at various levels. Hodge (1996) investigated that prevalence of stress were found particularly among those students who were by their nature prone to anxiety.

Tung and Chahal (2005) examined relationship between stress and adjustment and found no significical causal relationship between stress and the adjustment. However direction of the results implied that level of adjustment influences the number of stress full events and amount of stress experienced by them.

Adjustment refers to the process of accommodating oneself to circumstances, and more particularly to the satisfaction of needs or motives under various circumstances. An environment barrier may frustrate a person attracted to a positive goal. Then he has to make adjustments with that barrier person who overcomes that particular barrier have good adjustment. We all use defence mechanisms to protect ourselves against anxiety and fear, and certain ones are more used by some people that others. Each day we faced with new situations that demands decisions involve change in both our internal state and our external environment. According to Aggrawal (2004) the adjustment of adolescent very much depends on the fulfillment of their significant specific needs that consist of physical needs, emotional needs, social needs, intellectual needs, moral needs and vocational needs. It may be helpful, therefore, to devote a little more space to two important qualities of adjustment. First, it is a process that involves continuous changes and the second people develop consistent pattern of adjustment to these constant changes. Students make many transitions during their years of schooling: from home to school, middle to high school, and high school to college or work. These transitions are usually major events in the lives of students and parents. The stresses created by these transitions can be minimized when the new environment is responsive to each particular age group. This digest presents a brief overview of some of the issues involved in the transition from elementary to middle school and provide suggestions for transition programs and activities. There are two separate studies G.S.Gupta (1982) N.C.P.Sinha and M.Sharma (1978) in which the correlation between Adjustments was studied, but no consistent relationship was reported. Bhagia (1966) studied found that the girls exceed boys significantly in their adjustment to general environment and organizational aspect of the school. 
The basic aim of present investigation is that to study the influence of role of medium in the development of child's personality. Keeping in view the growing problem of academic stress among school students the study was undertaken to examine the level of academic stress among Guajarati and English medium school students and its probable impact on the overall adjustment among them.

\section{HYPOTHESES:}

The hypotheses are as follows:

1. Level of academic stress among English medium school students will be significantly higher than the Gujarati medium school students of both sexes.

2. Adjustment level of English medium school students will be significantly different from Gujarati medium school students of both sexes.

The rational for above hypothesis was based on assumption that the performance of school students was generally depended on mastery of language. The school students, who had good command and control over his language, could render the things in an adequate way.

\section{METHOD}

\section{Variables}

The variable of the present study were as under.

\begin{tabular}{|c|c|c|c|c|}
\hline No. & Name of the Variable & $\begin{array}{c}\text { Nature of } \\
\text { Variable } \\
1\end{array}$ & $\begin{array}{c}\text { Number } \\
\text { of Level }\end{array}$ & Name of the Levels \\
\hline Sex & $\begin{array}{c}\text { Independent } \\
\text { Variable }\end{array}$ & 2 & $\begin{array}{c}\text { School Boys, } \\
\text { School Girls }\end{array}$ \\
\hline 2 & $\begin{array}{c}\text { Medium of } \\
\text { Instruction }\end{array}$ & $\begin{array}{c}\text { Independent } \\
\text { Variable }\end{array}$ & 2 & English and Gujarati \\
\hline 3 & Academic Stress & $\begin{array}{c}\text { Dependent } \\
\text { Variable }\end{array}$ & 1 & $\begin{array}{c}\text { Score of Academic Stress } \\
\text { scale }\end{array}$ \\
\hline School Adjustment & $\begin{array}{c}\text { Dependent } \\
\text { Variable }\end{array}$ & 1 & $\begin{array}{c}\text { Score of School } \\
\text { Adjustment inventories }\end{array}$ \\
\hline
\end{tabular}




\section{RESEARCH DESIGN}

$2 \times 2$ factorial design is used for present investigation as follows.

FACTORIAL DESIGN $(2$ X 2) $=120$ SUBJECTS

\begin{tabular}{|c|c|c|}
\hline \multirow{2}{*}{ Medium of instruction (B) } & \multicolumn{2}{|c|}{ Sex (A) } \\
\cline { 2 - 3 } & School Boys (A1) & School Girls (A2) \\
\hline ENGLISH (B1) & 30 & 30 \\
\hline GUJARATI (B2) & 30 & 30 \\
\hline
\end{tabular}

\section{Sample}

Altogether 120 class IX and X students were randomly selected from different types of schools of Ahmedabad. Out of 120 students, 60 were taken from gujarati medium school and the remaining 60 were taken from English medium school of both sex.

\section{Tools}

For assessing academic stress of students a 80 items composite scale for assessing academic stress among students consisting of force choice type answer was used choice and higher score indicating academic stress. The scale was developed by Abha Rani Bist, (1987) Similarly, for examining the level of adjustment of the subjects, a 60 items scale developed by Sinha and Singh (1971) was administered on the sample. The scale consist of items in three different areas namely emotional, social and educational with 20 items each. The answer is forced choice and higher score indicating poor adjustment.

\section{RESULTS AND DISCUSSION:}

Table-1: Mean, SD and $t$ value of academic stress scores of students of Gujarati medium school $(n=60)$ and English Medium school $(n=60)$.

\begin{tabular}{|l|c|c|c|c|}
\hline \multirow{2}{*}{ GROUP } & \multicolumn{3}{|c|}{ ACADEMIC STRESS } & \multirow{2}{*}{ ' $t$ ' } \\
\cline { 2 - 4 } & N & M & SD & \\
\hline
\end{tabular}




\begin{tabular}{|c|c|c|c|c|}
\hline ENGLISH MEDIUM SCHOOL & 60 & 63.37 & 6.50 & \multirow{2}{*}{$8.12^{* *}$} \\
\cline { 1 - 4 } GUJARATI MEDIUM SCHOOL & 60 & 52.97 & 7.49 & \\
\hline
\end{tabular}

***Significant at .01 levels. $(2.62)$

From the results given in table 1, it appeared that magnitude of academic stress among high school students was found to be high particularly among the English medium school students as the mean scores were 63.37 and 52.97 respectively for English medium school and Gujarati medium school students. The difference in terms of academic stress between the two groups of students was also statistically tested by computing $t$ ratio which was also found significant $(t=8.12)$. Thus it can be said that Medium of Istruction, academic load and school environment of English medium school might be contributing towards enhancement of stress among students. Similar results were also obtained by Bohannon (2000). Hence it can be safely said that English Medium school students suffer from higher level of stress related to their academics. Thus hypothesis presuming higher level of academic stress among English medium school students of both sexes was found to be proved.

Table-2: Mean, SD and $t$ value of Adjustment scores of students of Gujarati medium school ( $\mathrm{n}=60)$ and English Medium school $(\mathrm{n}=60)$.

\begin{tabular}{|c|c|c|c|c|}
\hline \multirow{2}{*}{ Group } & \multicolumn{3}{|c|}{ TOTAL ADJUSTMENT } & \multirow{2}{*}{ 't' } \\
\cline { 2 - 4 } & $\mathbf{N}$ & M & SD & \\
\hline $\begin{array}{c}\text { ENGLISH MEDIUM } \\
\text { SCHOOL }\end{array}$ & 60 & 22.47 & 4.96 & \multirow{2}{*}{$8.21^{* *}$} \\
\hline $\begin{array}{c}\text { GUJARATI MEDIUM } \\
\text { SCHOOL }\end{array}$ & 60 & 15.98 & 3.59 & \\
\hline
\end{tabular}

**Significant at .01 levels. (2.62)

Results given in table II, Indicating the level of overall adjustment among school students revealed that overall adjustment of English medium school students was more poor than the Gujarati medium school students as the mean scores for adjustment were found to be 22.47 and 15.98 respectively for the English and Gujarati medium school students. The difference between the two groups of students with regard to their level of adjustment was also statistically tested and found significant $(\mathrm{t}=8.21)$. Isakson (1999) have also found that adolescents experienced significant changes during the initial transition into high school that were related to sense of school membership etc. was also related to adolescents' adjustment to the transition. Hence 
adjustment among English medium school students was found to be poor probably because they suffer from high level of academic stress. Thus hypothesis of significant difference between the two groups of students with regard to their level of adjustment was also found to be proved.

Table N0.3: Showing Results of Analysis of Variance on Academic Stress in relation to Sex and Medium of instruction.

\begin{tabular}{|c|c|c|c|c|c|}
\hline $\begin{array}{c}\text { Source of Variance } \\
\text { A }\end{array}$ & Sum of Square & df & Mean Sum of Square & F & Sign. \\
\hline (Sex) & 1140.833 & 1 & 1140.833 & $28.483^{*}$ & .01 \\
\hline B & 3244.800 & 1 & 3244.800 & $81.012^{*}$ & .01 \\
\hline $\begin{array}{c}\text { (Medium of Instruction) } \\
\text { (Sex x Medium of Instruction) }\end{array}$ & 20.833 & 1 & 20.833 & 0.520 & NS \\
\hline A x B & 4666.200 & 116 & 40.053 & & \\
\hline Error & 9052.667 & 119 & & & \\
\hline Total & & & & & \\
\hline
\end{tabular}

*Significant at .01 levels $=3.91$

As per Table No.3, an attempt is made to find out the difference between boys and girls on Academic Stress with the ANOVA Test. The F - ratio of sex is 28.483 which are significant. It means boys and girls group differ significantly on Academic Stress score. So we can say that sex effects on their Academic Stress.

As regards the medium of instruction variable, the mean score on the two groups, English medium students $(\mathrm{M}=63.37)$ and Gujarati medium students $(\mathrm{M}=52.97)$ and as given in Table No.1 The overall difference was found significant ( $\mathrm{F}=81.012$, sign. at .01) It means Gujarati and English medium school students group differ significantly on Academic Stress score. So we can say that medium of instruction effects on their Academic Stress.

Table No.3, Shows the F - ratio of sex x medium of instruction is 0.520 , which is insignificant. It means there is no significant interaction between sex $x$ medium of instruction. Sex $x$ medium of instruction do not effect on Academic Stress. 
Table N0.4: Showing Results of Analysis of Variance on Adjustment in relation to Sex and Medium of instruction.

\begin{tabular}{|c|c|c|c|c|c|}
\hline $\begin{array}{c}\text { Source of Variance } \\
\text { Sum of Square }\end{array}$ & df & $\begin{array}{c}\text { Mean Sum of } \\
\text { Square }\end{array}$ & F & Sign. \\
\hline A & 533.08 & 1 & 533.08 & $37.108^{*}$ & .01 \\
\hline B & 1261.008 & 1 & 1261.008 & $87.726^{*}$ & .01 \\
\hline (Medium of Instruction) & & & & \\
\hline A x B & 9.075 & 1 & 9.075 & 0.631 & NS \\
\hline Error & 1667.433 & 116 & 14.377 & & \\
\hline Total & 3470.925 & 119 & & & \\
\hline
\end{tabular}

*Significant at .01 levels 3.91

As per Table No.4, an attempt is made to find out the difference between boys and girls on Adjustment with the ANOVA Test. The F - ratio of sex is 37.108 which are significant. It means boys and girls group differ significantly on Adjustment score. So we can say that sex effects on their Adjustment.

As regards the medium of instruction variable, the mean score on the two groups, English medium students $(M=22.47)$ and Gujarati medium students $(M=15.78)$ and as given in Table No.1 The overall difference was found significant ( $\mathrm{F}=87.726$, sign. at .01) It means Gujarati and English medium school students group differ significantly on total adjustment score. So we can say that medium of instruction effects on their total adjustment.

Table No. 4, Shows the F - ratio of sex x medium of instruction is 0.631 , which is insignificant. It means there is no significant interaction between sex $x$ medium of instruction. Sex $x$ medium of instruction do not effect on school Adjustment.

\section{CONCLUSION:}

1) There is a significant difference between students of Gujarati medium school and that of English medium school in the area of academic Stress. Students of English medium school are high academic Stress than Gujarati medium school. It means students of English 
medium school have higher academic Stress, which state they have an impending fear from the environment in the form of teacher and subject.

2) There is a significant difference between students of Gujarati medium school and that of English medium school in the area of total adjustment. Students of Gujarati medium school well adjusted than the English medium school students.

\section{REFERENCES}

1) Abha Rani Bisht (1987). Bisht Battery of Stress (BBSS), National Psychological Corporation, Agra, India.

2) Aggrawal, J.C. (2004). Psychology of learning and Development, Shipra Publication, Delhi.

3) Bhagia N.M. (1966) Study of the problem of School Adjustment and development an Adjustment Inventory. Unpublished Ph. D. Thesis, M.S. University, Baroda.

4) Bhargavi Devi (1995) Academic stress and anxiety in elementary school children. An unpublished MSc Dissertation submitted to S V U Tirupati.

5) Bohannon, A.P. (2000). The relationship of School related stressors to discipline Academic Stress and Adjustment referrals, attendance, grade point average and under achievement among high school students. Dissertation Abstracts International, 57, 1482.

6) Dawood, N. (1995). Stressors encountered by junior high school students and their relation to grade point average, sex and grade. Jordan, Deanship of Academic Research, 22, 36713706.

7) Hodge, Glenda Mae (1996). Adolescent Anxiety, distress and coping: A study of senior school students and higher school certificate examination stress. Dissertation Abstract International, 57, 0114.

8) Isakson, K. (1999). The adjustment of adolescents during the transition into high school: A short-term longitudinal study. Journal of Youth and Adolescence, 28, 1- 26.

9) Sinha, A.K.P. and Singh, R.P. (1971). Adjustment Inventory for school students. National Psychological Corporation, Agra, India.

10) Tung, S. and Chahal, N. (2005). Relationship between Stress and Adjustment Adolescents females; A causal study , Journal of Personality study and Group Behavior , Amritsar, 25, 19-31. 